\title{
KEEFEKTIFAN PEMBELAJARAN E-LEARNING BERBASIS WEBSITE PADA MATA KULIAH TEORI BILANGAN DI IKIP PGRI SEMARANG
}

\author{
Muhammad Prayito \\ IKIP PGRI SEMARANG \\ mprayito@gmail.com
}

\begin{abstract}
The aim of this study is to know the effectiveness of learning based on Web at Number Theory lesson at IKIP PGRI Semarang. The implementation is focused at FPMIPA IKIP PGRI Semarang in fifth semester of mathematics education students which contain of 9 classes. Sampling technique in this study use convenience sampling procedure, where as the experimental is $5 B$ and $5 \mathrm{~A}$ as the control class and $5 \mathrm{G}$ as a class test. Independent variable of this research is the activity of student and learning result as dependent variable. The Data is obtained through observation and tests then we analyze by t test and regression test..

The results showed that implementation of learning achieve effective with characterized by: a) Mean of student learning result greater than $K K M=75$, and in classical is more than $85 \%$ of students achieve point at 75 . b) Effect of activity on the results of study is ^

$Y=-10,460+1,305 X_{1}$ means that the active variable $(X)$ gives a positive effect on learning result $(Y)$. The value of the effect of creativity on learning result can be seen by $R$ value in the table of Summary Model $0.867=86.7 \%$. The Value indicates that the creativity of students affect learning result at 86.7\%. c) The Mean of experimental class is 80.94 and 62.60 for the control class, so the class of experiments significantly better than the the control class. Based on the above explanation we conclude that learning based on web at Number Theory in Semarang PGRI IKIP is effective.
\end{abstract}

Keywords: Effectiveness, E-Learning, Website

ABSTRAK. Penelitian ini memiliki tujuan untuk mengetahui efektivitas pembelajaran ELearning berbasis Website pada mata kuliah Teori Bilangan di IKIP PGRI Semarang. Implementasi lapangan difokuskan di FPMIPA IKIP PGRI semarang program studi pendidikan matematika semester 5 yang memiliki 9 kelas. Teknik pengambilan sampel dalam penelitian ini adalah convenience sampling procedure, terpilih 5B sebagai kelas eksperimen dan $5 A$ sebagai kelas kontrol serta kelas $5 G$ sebagai kelas uji coba. Variabel independen penelitian adalah keaktifan mahasiswa dan variabel dependen adalah hasil belajar. Data diperoleh melalui observasi dan tes kemudian diolah dengan uji t dan uji pengaruh regresi. 
Hasil penelitian menunjukkan bahwa Implementasi pembelajaran mencapai efektif yang ditandai oleh: a) Rataan hasil belajar siswa secara individu melebihi $K K M=75$, dan secara klasikal lebih dari 85\% siswa memperoleh nilai 75. b) Pengaruh keaktifan terhadap hasil belajar dengan persamaan $\hat{Y}=-10,460+1,305 X_{1}$ artinya variable keaktifan (X) memberikan pengaruh positif terhadap hasil belajar $(Y)$. Besarnya pengaruh kreativitas terhadap hasil belajar dilihat dari nilai $R$ pada tabel Model Summary didapat 0,867 = 86,7\%. Nilai tersebut menunjukkan bahwa kreativitas peserta didik mempengaruhi hasil belajar sebesar 86,7\%. c) Rataan kelas eksperimen sebesar 80,94 dan kelas kontrol sebesar 62,60, maka kelas eksperimen memiliki rataan hasil belajar lebih baik secara signifikan dari pada rataan kelas kontrol. Berdasarkan ketiga hal tersebut diatas pembelajaran E-Learning berbasis Website pada mata kuliah Teori Bilangan di IKIP PGRI Semarang efektif.

Kata Kunci: Efektivitas, E-Learning, Website

\section{PENDAHULUAN}

\section{A. Latar Belakang}

Paradigma baru pendidikan matematika menghendaki dilakukan inovasi yang terintegrasi dan berkesinambungan. Salah satu wujudnya adalah inovasi yang dilakukan oleh pemerintah dengan usaha untuk membentuk sebuah jaringan pendidikan nasional. Pada bulan Maret 2007 Jaringan Pendidikan Nasional (JARDIKNAS) diresmikan saat acara pembukaan konferensi menteri-menteri pendidikan Asia Tenggara. Jaringan berbasis teknologi informasi dan komunikasi (ICT) tersebut ditujukan untuk menghubungkan 533 simpul di 33 provinsi, 441 kota/kabupaten, lebih dari 3.600 Sekolah Menengah dan lebih dari 84 perguruan tinggi, serta 61 kantor dinas pendidikan di seluruh Indonesia (Isjoni, Ismail, dan Mahmud 2008: 17).

Menurut data nilai mata kuliah teori bilangan dari dosen yang mengampu teori bilangan bahwa hasil pembelajaran pada mata kuliah teori bilangan masih rendah dengan rata-rata 68 karena belum sesuai dengan perencanaan dari tim yang mentargetkan nilai KKM (Kriteria Ketuntasan minimum berdasarkan PAP) adalah 75. Wawancara dengan dosen-dosen mata kuliah teori bilangan sebelumnya menyatakan bahwa sumber materi teori 
bilangan masih terbatas. Keaktifan mahasiswa pada mata kuliah inipun masih kurang karena mahasiswa sangat bergantung pada dosen. Dengan adanya penyajian materi teori bilangan dalam bentuk website diharapkan akan menjadi satu khasanah baru dalam suasana perkuliahan. Selain menambah sumber pembelajaran untuk mahasiswa juga diharapkan akan membuat mahasiswa semakin aktif dalam pembelajaran. Sehingga Permasalahan dalam penelitian ini adalah: "Apakah penerapan pembelajaran E-Learning berbasis Website pada mata kuliah Teori Bilangan di IKIP PGRI Semarang efektif?”

\section{B. Rumusan masalah}

Permasalahan dalam penelitian ini adalah: "Apakah penerapan pembelajaran E-Learning berbasis Website pada mata kuliah Teori Bilangan di IKIP PGRI Semarang efektif?”

\section{Tujuan}

Tujuan yang ingin dicapai melalui penelitian ini adalah untuk mengetahui efektivitas pembelajaran E-Learning berbasis Website pada mata kuliah Teori Bilangan di IKIP PGRI Semarang.

\section{Manfaat}

Adapun Adapun manfaat yang diharapkan dari hasil penelitian, sebagai berikut:

1) Melalui penelitian ini diharapkan dapat memberikan suatu referensi para dosen tentang pembelajaran/ media yang digunakan untuk meningkatkan hasil belajar mahasiswa.

2) Melalui pembelajaran menggunakan E-Learning berbasis Website, mahasiswa diharapkan terfasilitasi untuk mengembangkan kemampuan teori bilangan serta aplikasinya.

3) Penelitian ini juga diharapkan dapat membantu IKIP PGRI semarang untuk menciptakan lulusan yang tidak hanya menguasai pengetahuan tetapi memiliki daya saing tinggi berbekal kemampuan teknologi 


\section{METODE PENELITIAN}

\section{A. Desain Penelitian}

Desain penelitian ini menggunakan jenis penelitian Quasi-Experimental, yang dapat dilihat pada gambar 3.1 berikut.

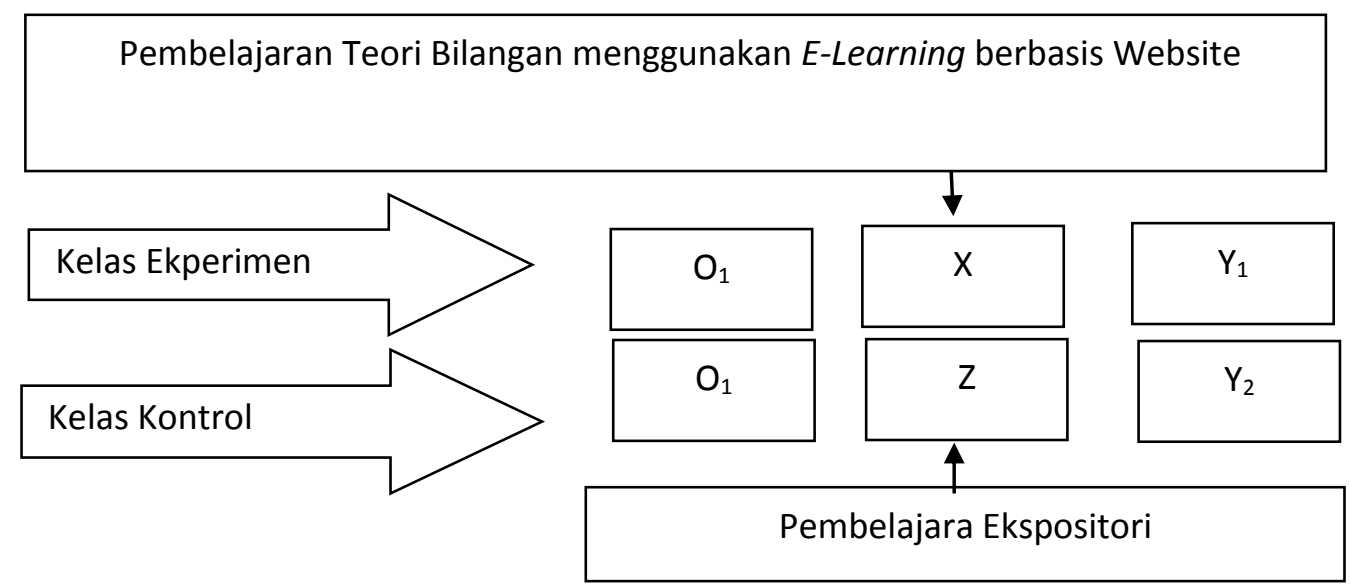

Gambar 1 Desain Quasi Esperimen (Samsudi, 2006: 75)

Keterangan:

O : Nilai Pre Test Teori Bilangan.

Y : Keefektivan pembelajaran (Ketuntasan, pengaruh aktivitas terhadap prestasi belajar, dan perbandingan prestasi belajar mahasiswa)

X:Treatment atau perlakuan dengan pembelajaran Teori Bilangan menggunakan E-Learning berbasis Web.

Z : Pembelajaran Teori Bilangan melalui pembelajaran ekspositori.

\section{B. Waktu dan Tempat Penelitian}

Penelitian ini akan dilaksanakan pada pertengahan semester gasal tahun ajaran 2011-2012, tepatnya pada bulan Oktober-November. Adapun tempat pelaksanaan penelitian di lakukan di lingkungan IKIP PGRI Semarang. 


\section{Populasi dan Sampel Penelitian}

Populasi dalam penelitian ini adalah mahasiswa IKIP PGRI Semarang, jurusan pendidikan matematika semester 1 tahun ajaran 2011-2012. Sedangkan sampelnya ialah mahasiswa semester 5 yang mengambil mata kuliah teori bilangan, terdiri dari: kelas eksperimen, kelas kontrol. Teknik pengambilan sampel dalam penelitian ini adalah convenience sampling procedure (Halat, 2006) dimana pengambilan sampel hanya berdasar hasil uji homogenitas dan rata-rata kelas saja.

\section{Instrumen Penelitian}

Instrumen yang digunakan dalam penelitian ini, sebagai berikut:

1) Website teori bilangan, digunakan sebagai sarana pemberian materi dan tugas kelompok mahasiswa

2) Lembar tugas mahasiswa, digunakan sebagai sarana pemberian tugas mandiri pada mahasiswa.

3) Bank soal, berisi soal terbuka dengan alternatif jawaban lebih dari satu. Digunakan sebagai sarana pengembangan dan aplikasi konsep.

4) Lembar pengamatan keaktivan mahasiswa, digunakan selama pembelajaran untuk mengamati aktivitas mahasiswa khususnya yang berkaitan dengan pengembangan kemampuan berpikir kritis dan kreatif mahasiswa.

5) Soal hasil belajar, untuk mengetahui tingkat kemampuan hasil belajar mahasiswa menggunkan pembelajaran E-Learning berbasis Website.

\section{E. Teknik Pengumpulan Data}

Teknik pengumpulan data yang digunakan menggunakan metode:

1. Metode Tes

Metode ini digunakan untuk memperoleh data pre test guna menentukan kelas kontrol dan kelas eksperimen serta untuk memperoleh nilai hasil belajar mahasiswa.

2. Metode Observasi 
Metode ini digunakan untuk memperoleh data tentang aktifitas mahasiswa pada saat pembelajaran berlangsung.

\section{F. Teknik Analisis Data}

1. Analisis Data Awal

Analisis penentuan kelas eksperimen dan kelas kontrol dari data nilai pre test mata kuliah teori bilangan semester 1 .

a. Uji Normalitas

Uji ini dimaksudkan untuk mengetahui apakah data yang digunakan merupakan data yang berdistribusi normal atau tidak. Dalam menganalisis normalitas dalam penelitian ini menggunakan uji Kolmogorov-Smirnov berbantuan program SPSS 16.

b. Uji Homogenitas dan Uji Kesamaan Rata-rata

Analisis ini digunakan untuk mengetahui apakah kelas eksperimen dan kontrol berasal dari populasi yang homogen atau tidak serta apakah memiliki rata-rata yang berbeda signifikan atau tidak. Hal ini digunakan untuk menentukan bahwa kedua kelas sebelum diberikan perlakuan berawal dari start yang sama. Dalam menganalisis homogenitas dalam penelitian ini menggunakan uji Independent Sample $t$ Test dengan bantuan program SPSS 16.

\section{Analisis Data Untuk Merevisi Perangkat Tes}

a. Analisis Validitas Butir Soal (Item Tes)

Validitas item (butir soal) dihitung untuk mengetahui seberapa jauh hubungan antara jawaban suatu butir soal dengan skor total yang telah ditetapkan. Secara umum, suatau butir soal dikatakan valid apabila memiliki dukungan yang besar terhadap skor total. Skor pada suatu item menyebabkan skor total menjadi tinggi atau rendah.

Dengan kata lain sebuah item tes memiliki validitas tinggi jika skor pada item itu mempunyai kesejajaran dengan skor total. 
Kesejajaran ini dapat diartikan dengan korelasi, sehingga untuk mengatahui validitas item ini digunakan rumus korelasi product moment sebagai berikut:

$$
\mathbf{r}_{x y}=\frac{N \sum x y-\left(\sum x\right)\left[\sum y\right]}{\sqrt{\left\{N \sum x^{2}-\left(\sum x\right)^{2}\right\}\left\{N \sum y^{2}-\left(\sum y\right)^{2}\right\}}}
$$

Hasil perhitungan $r_{x y}$ dikonsultasikan pada Tabel kritis $r$ product moment dengan signifikansi 5\%. Jika $\mathrm{r}_{\mathrm{xy}}>\mathrm{r}_{\text {kritis, }}$, maka butir soal tersebut valid.

b. Analisis Reliabilitas Perangkat Tes

Reliabilitas perangkat tes dihitung untuk mengetahui ketetapan hasil tes. Untuk menghitung reliabelitas perangkat tes ini digunakan rumus yang sesuai dengan bentuk tes uraian (essay), yaitu rumus alpha sebagai berikut:

$$
\begin{aligned}
& \mathrm{r}_{11}=\left(\frac{n}{(n-1)}\right)\left[1-\frac{\sum \sigma_{x}^{2}}{\sigma^{2}}\right] \\
& \text { dengan } \sigma_{x}^{2}=\frac{\sum x^{2}-\frac{\left(\sum x\right)^{2}}{N}}{N-1} \text { dan } \sigma_{t}^{2}=\frac{\sum x_{t}^{2}-\frac{\left(\sum x_{t}\right)^{2}}{N}}{N-1}
\end{aligned}
$$

Hasil perhitungan $\mathrm{r}_{\mathrm{xy}}$ dikonsultasikan pada tabel kritis $\mathrm{r}$ product moment dengan signifikansi 5\%. Jika $\mathrm{r}_{\mathrm{xy}}>\mathrm{r}_{\text {kritis, }}$, maka butir soal tersebut reliabel.

c. Tingkat Kesukaran

Rumus yang digunakan untuk mencari tingkat kesukaran adalah:

$$
\mathrm{P}=\frac{B}{J_{S}}
$$


Tabel 3.1: Kriteria Indeks Tingkat Kesukaran Soal

\begin{tabular}{|r|l|}
\hline Indeks $(\mathrm{P})$ & Keterangan \\
\hline $0,00 \leq \mathrm{x} \leq 0,30$ & Soal sukar \\
$0,30<\mathrm{x} \leq 0,70$ & Soal sedang \\
$0,70<\mathrm{x} \leq 1,00$ & Soal mudah \\
\hline
\end{tabular}

d. Daya Beda

Teknik yang digunkan untuk menghitung daya pembeda bagi tes bentuk uraian adalah dengan menghitung perbedaan dua buah rata-rata yaitu antara rata-rata kelompok atas dengan rata-rata kelompok bawah untuk tiap-tiap item. Kelompok atas adalah $27 \%$ bagian atas dari peserta tes setelah nilai tes diurutkan dari terbesar ke terkecil sedangkan kelompok bawah adalah $27 \%$ dari bagian bawah. Rumus yang digunakan sebagai berikut.

$$
t=\frac{M H-M L}{\sqrt{\frac{\sum x_{1}^{2}+\sum x_{2} 2}{n_{i}\left(n_{i}-1\right)}}}
$$

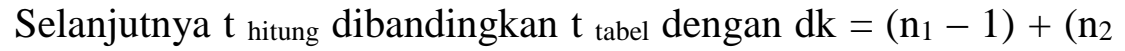
- 1) dengan $\alpha=5 \%$. Dengan kriteria jika $t$ hitung $>t$ tabel maka daya pembeda soal itu signifikan sedangkan jika $t_{\text {hitung }}<t_{\text {tabel }}$ maka daya pembeda soal tidak signfikan.

3. Analisis Data Akhir

a. Prestasi belajar peserta didik mencapai ketuntasan yang diinginkan.

1) Uji Ketuntasan Klasikal 
Untuk menguji pencapaian ketuntasan belajar yang diprogramkan pada keaktifan peserta didik pada kelompok eksperimen digunakan uji t satu sampel (uji dua pihak).

$\mathrm{H}_{0}: \mu=75$ (Prestasi belajar peserta didik kelompok eksperimen mencapai rata-rata ketuntasan belajar yang diprogramkan 75).

$\mathrm{H}_{1}: \mu \neq 75$ (Prestasi belajar kelompok eksperimen tidak mencapai ratarata ketuntasan belajar yang diprogramkan 75).

Untuk pengujian hipotesis di atas maka pengujiannya dilakukan dengan uji dua pihak. Rumus uji statistik untuk menghitung t.

$$
\mathrm{t}=\frac{\bar{X}-\mu_{0}}{\frac{s}{\sqrt{n}}}
$$

Terima $\mathrm{H}_{0}$ jika $\mathrm{t}_{\text {hitung }} \leq \mathrm{t}_{\text {tabel }}$ artinya prestasi belajar peserta didik sudah mencapai ketuntasan belajar yang diprogramkan. Pengujian hipotesis dapat dilakukan dengan, one-Sample t Test dengan bantuan program SPSS versi 16. Kriteria yang digunakan ialah $\mathrm{H}_{0}$ diterima jika $\operatorname{sig}>\alpha$.

2)Uji Ketuntasan Individual

Uji Proporsi digunakan untuk mengetahui proporsi data prestasi belajar peserta didik kelompok eksperimen yang mencapai ketuntasan dan yang tidak mencapai ketuntasan. Hal ini nantinya untuk menyimpulkan apakah prestasi belajar peserta didik kelompok eksperimen tuntas secara individual yaitu dengan proporsi peserta didik yang mencapai ketuntasan $\geq$ $80 \%$ (Clark, Guskey, \& Benninga: 1983).

$\mathrm{H}_{0}: \pi=80 \%$ (Proporsi siswa yang mencapai KKM 65 adalah 80\%)

$\mathrm{H}_{1}: \pi \neq 80 \%$ (Proporsi siswa yang mencapai KKM 65 tidak sama dengan $80 \%)$ 
Untuk pengujian hipotesis di atas maka pengujiannya dilakukan dengan uji proporsi pihak kanan . Rumus uji statistik untuk menghitung z.

$$
\mathrm{z}=\frac{\frac{x}{n}-\pi_{0}}{\sqrt{\frac{\pi_{0}\left(1-\pi_{0}\right)}{n}}}
$$

Tolak $\mathrm{H}_{0}$ jika $\mathrm{Z}_{\text {hitung }} \geq \mathrm{z}_{0,5}-\alpha$ artinya prestasi belajar peserta didik sudah mencapai ketuntasan belajar yang diprogramkan (Sudjana, 2002: 248).

b. Berpengaruhnya aktivitas peserta didik terhadap prestasi belajar peserta didik

Uji linieritas antara aktivitas terhadap prestasi belajar

$\mathrm{H}_{0}: \beta=0$, aktivitas tidak linier terhadap prestasi belajar

$\mathrm{H}_{1}: \beta \neq 0$, aktivitas linier terhadap prestasi belajar

Untuk menguji hubungan kelinieran data digunakan hubungan persamaan regresi dengan rumus $: \hat{Y}=a+b X$, dimana data yang memilki $\left(x_{1}, y_{1}\right),\left(x_{2}, y_{2}\right), \ldots,\left(x_{n}, y_{n}\right)$

$a=\frac{\left(\sum y_{1}\right)\left(\sum x_{1}^{2}\right)-\left(\sum x_{i}\right)\left(\sum x_{i} y_{i}\right)}{n \sum x_{i}^{2}-\left(\sum y_{i}\right)^{2}}$ dan $\quad b=\frac{n \sum x_{i} y_{i}-\left(\sum x_{i}\right)\left(\sum y_{i}\right)}{n \sum x_{i}^{2}-\left(\sum x_{i}\right)^{2}}$

dengan

$x_{i}=$ nilai subyek ke-i pada variabel independen

$y_{i}=$ nilai subyek ke-i pada variabel dependen

Untuk menguji kelinieran model di atas digunakan Tabel 2 
Tabel. 2 Rancangan Pengujian Kelinieran Regresi

\begin{tabular}{|l|l|l|l|l|}
\hline Sumber & $\begin{array}{l}\text { JK (Jumlah } \\
\text { Kuadrat) }\end{array}$ & $\begin{array}{l}\text { Derajat } \\
\text { Kebebasan }\end{array}$ & RK & F \\
\hline Regresi & $\begin{array}{l}\text { JKR= } \\
\sum\left(\hat{Y}_{1}-Y\right)^{2}\end{array}$ & 1 & $\begin{array}{l}\text { RKR } \\
=\frac{J K R}{1}\end{array}$ & Fh $=\frac{R K R}{R K S}$ \\
\hline Sisa & $\begin{array}{l}\text { JKS }= \\
\sum\left(Y_{i}-\hat{Y}_{i}\right)^{2}\end{array}$ & $\mathrm{n}-2$ & $\begin{array}{l}\text { RKS } \\
=\frac{J K S}{n-2}\end{array}$ & \\
\hline Total & $\begin{array}{l}\mathrm{JKT}= \\
\sum\left(Y_{i}-\bar{Y}\right)^{2}\end{array}$ & $\mathrm{n}-1$ & & \\
\hline
\end{tabular}

Berlaku hubungan JKT $=\mathrm{JKR}+\mathrm{JKS}$

Apabila $F_{\text {hitung }}>F_{\text {Total }}$ maka artinya signifikan atau model adalah linier. $F_{\text {total }}$ dicari dengan menggunakan tabel distribusi $\mathrm{F}$ dengan derajat kesalahan $\alpha=5 \%$ dengan derajat kebebasan 1 dan (n-2). Setelah model tersebut diuji dan dapat diketahui bahwa ternyata model adalah linier, maka selanjutnya ditentukan besarnya pengaruh variabel $\mathrm{X}$ terhadap variabel $\mathrm{Y}$.

Untuk menguji hipotesis keberartian dapat dilihat Anova output pada Anova output SPSS versi 16 dengan nilai sig< $5 \%$, maka $\mathrm{H}_{0}$ ditolak yang mempunyai arti bahwa antara keaktifan dengan prestasi belajar mempunyai hubungan yang berarti.

c. Prestasi belajar kelas eksperimen dibanding kelas kontrol

Untuk melakukan uji perbedaan rataan prestasi belajar peserta didik kelompok eksperimen dan kelompok kontrol ini digunakan uji t. Sebelum 
pemilihan rumus uji $\mathrm{t}$ yang tepat maka dilakukan uji kesamaan varian terlebih dahulu. Syarat uji kesamaan varian adalah sbb.

$\mathrm{H}_{0}$ : varian kedua kelompok sama ( homogen)

$\mathrm{H}_{1}$ : varian kedua kelompok tidak sama tidak homogen

Rumus yang digunakan:

$$
\mathrm{F}=\frac{\text { var ians besar }}{\text { var ians kecil }}
$$

Kemudian nilai $\mathrm{F}$ dicocokkan dengan $\mathrm{F}$ Tabel dengan melihat dk pembilang $\mathrm{n}_{1-1}$ dan dk penyebut $\mathrm{n}_{2}-1 \mid F$.hitung $\mid>\mathrm{F}$ Tabel artinya signifikan Ho ditolak.

1) Uji dua variabel kasus varian sama.

$\mathrm{H}_{0}: \mu_{1}=\mu_{2}$ (rata-rata kelas eksperrimen sama dengan kelas kontrol)

$\mathrm{H}_{1}: \mu_{1} \neq \mu_{2}$ (rata-rata kelas eksperrimen berbeda dengan kelas kontrol)

Rumus uji statistika untuk varian sama: $t=\frac{\bar{x}_{1}-\bar{x}_{2}}{\sqrt{S^{2}\left(\frac{1}{n_{1}}+\frac{1}{n_{2}}\right)}}$.

$$
\begin{aligned}
& \text { Dimana } S^{2}=\frac{\left(n_{1}-1\right) S_{1}^{2}+\left(n_{2}-1\right) S_{2}^{2}}{n_{1}+n_{2}-2} \quad \cdot \quad \text { Terima } \mathrm{H}_{0} \text { jika } \\
& -t_{1-\frac{1}{2} \alpha, n_{1}+n_{2}-1}<t<t_{1-\frac{1}{2} \alpha, n_{1}+n_{2}-1}
\end{aligned}
$$

2) Uji dua variabel kasus varian tidak sama.

$\mathrm{H}_{0}: \mu_{1}=\mu_{2}$ (rata-rata kelas eksperrimen sama dengan kelas kontrol)

$\mathrm{H}_{1}: \mu_{1} \neq \mu_{2}$ (rata-rata kelas eksperrimen berbeda dengan kelas kontrol) 
Rumus uji statistika untuk varian berbeda $: t^{\prime}=\frac{\overline{x_{1}-\bar{x}_{2}}}{\sqrt{\frac{S_{1}^{2}}{n_{1}}+\frac{S_{2}^{2}}{n_{2}}}}$

Dimana $S^{2}=\frac{\left(n_{1}-1\right) S_{1}^{2}+\left(n_{2}-1\right) S_{2}^{2}}{n_{1}+n_{2}-2}$

Terima $\mathrm{H}_{0}$ jika $-t_{1-\frac{1}{2} \alpha, n_{1}+n_{2}-1}<t<t_{1-\frac{1}{2} \alpha, n_{1}+n_{2}-1}$

Pengujian hipotesis dapat dilakukan dengan menggunakan SPSS 16, uji Independent sampel $t$ Test dengan kriteria $\mathrm{H}_{0}$ diterima jika sig $>\alpha$.

\section{HASIL DAN PEMBAHASAN (ATAU JUDUL LAIN YANG SESUAI)}

\section{A. Prestasi belajar mencapai kriteria ketuntasan minimal.}

Hasil analisis statistik menggunakan uji ketuntasan klasikal kelas uji coba dihasilkan bahwa nilai pada kolom sig (2-tailed) adalah 0,000, dimana $0,000<0,05$. Artinya $\mathrm{H}_{0}$ ditolak, maka dapat disimpulkan bahwa nilai rata-rata kelas eksperimen mencapai ketuntasan yang ditargetkan yaitu 75. Dengan kata lain siswa kelas eksperimen mencapai ketuntasan secara klasikal.

Uji proporsi untuk mengetahui tingkat ketuntasan siswa secara individual. Uji proporsi dengan menggunakan taraf nyata $5 \%$ diperoleh $\mathrm{Z}_{\text {tabel }}=1,68$, berarti $\mathrm{H}_{0}$ diterima jika $-1,68<\mathrm{Z}_{\text {hitung }}<1,68$. Karena diperoleh nilai $\mathrm{Z}_{\text {hitung }}=0,39$, maka $\mathrm{H}_{0}$ diterima, artinya proporsi ketuntasan belajar peserta didik secara individual adalah $80 \%$.. Hal ini berarti bahwa proporsi siswa yang mencapai kriteria ketuntasan 75 adalah lebih dari $80 \%$ dari keseluruhan siswa yang mengikuti tes. Jadi dapat 
disimpulkan bahwa hasil belajar siswa kelas eksperimen tuntas secara klaksikal dan individul.

Hasil perhitungan statistik menunjukkan bahwa penelitian ini mendukung teoriteori atau hasil penelitian yang telah dilakukan Center for Applied Special Technology (Isjoni dkk, 2008:15) menyebutkan bahwa pemanfaatan internet sebagai media pendidikan menunjukkan dampak yang baik terhadap prestasi belajar peserta didik.

\section{B. Berpengaruhnya keaktifan peserta didik terhadap prestasi belajar}

Melalui analisis Regressions dengan bantuan SPSS 16 diperoleh Besarnya pengaruh kreativitas terhadap hasil belajar dilihat dari nilai $\mathrm{R}$ pada tabel Model Summary didapat $0,867=86,7 \%$. Nilai tersebut menunjukkan bahwa kreativitas peserta didik mempengaruhi hasil belajar sebesar $86,7 \%$. Hal ini sangat mendukung hasil penelitian penelitian Bahbahani (2006) yang mengatakan bahwa penggunaan variasi konstruktivis dalam pembelajaran mempengaruhi prestasi, motivasi dan aktualisasi diri peserta didik.

\section{Prestasi belajar kelompok uji coba lebih baik dibandingkan kelompok kontrol}

Hasil tes prestasi belajar kelompok eksperimen dan kelompok kontrol diperoleh 80,94 untuk kelas eksperimen dan 62,60 untuk kelas kontrol. Hasil tersebut menunjukan bahwa prestasi belajar kelas eksperimen lebih baik dibandingkan dengan kelas kontrol.

Keefektifan perangkat pembelajaran pada kelompok uji coba ini sealur dengan pendapat Davis dan Sorrell (1995) yang menggunakan tiga kriteria untuk menyatakan pembelajaran yang efektif dalam penelitiannya yaitu pencapaian ketuntasan dalam belajar oleh peserta didik, berpengaruhnya keaktifan terhadap prestasi belajar serta 
hasil prestasi belajar yang lebih baik ketika dibandingkan dengan hasil prestasi belajar kelas konvensional dalam kasus ini menggunakan model kooperatif.

Berdasarkan hasil penelitian ini diperoleh bahwa melalui pembelajaran matematika berbantuan E-learning, mahasiswa mampu melihat suatu masalah dari berbagai sudut pandang dengan pemikiran penyelesaian yang lebih dari satu alternatif sehingga kecerdasan emosional peserta didik juga akan berkembang. Hal ini sejalan dengan hasil penelitian Ritz (2009: 15), Barbour (2005: 35), Hershkowitz dan Schawrz (1999: 164), dan Bahbahani (2006: 1).

\section{KESIMPULAN DAN SARAN}

Dengan mencermati hasil tes hasil belajar mahasiswa diperoleh bahwa penggunaan pembelajaran E-Learning berbasis Website pada mata kuliah Teori Bilangan menghasilkan pembelajaran yang efektif yang ditunjukan oleh: (1) tercapainya batas ketuntasan 75 baik secara klasikal maupun secara individual dengan besar proporsi mahasiswa yang mencapai ketuntasan lebih dari 80\%; (2) berpengaruhnya aktivitas mahasiswa terhadap hasil belajar mahasiswa; dan (3) Hasil belajar mahasiswa pada kelas eksperimen lebih baik dibandingkan dengan kelas kontrol.

Berdasarkan hasil penelitian ini, beberapa rekomendasi/saran yang dapat peneliti kemukakan adalah hendaknya banyak dosen yang sudah mulai menggunakan teknologi internet guna menunjang pembelajaran kearah yang lebih baik.

\section{UCAPAN TERIMAKASIH}

Terselesaikannya penulisan laporan penelitian ini tidak terlepas dari bantuan dan dukungan dari berbagai pihak. Oleh karena itu, dalam kesempatan ini penulis ingin memberikan ucapan terima kasih dan penghargaan yang setinggi-tingginya 
kepada mereka yang telah membantu penulis dalam menyelesaikan penelitian ini. Ucapan terima kasih dan penghargaan penulis ucapkan kepada yang terhormat:

1. Muhdi, SH., M.Hum,. Rektor IKIP PGRI Semarang.

2. Ir. Suwarno Widodo, M.Si., Kepala LPPM IKIP PGRI semarang.

3. Pihak-pihak yang membantu penelitian ini.

Akhirnya semoga bantuan yang telah diberikan kepada penulis, mendapat balasan yang indah dari Tuhan yang maha murah. Penulis menyadari tulisan ini masih banyak kekurangan, oleh karena itu segala saran dan kritik akan selalu penulis harapkan demi perbaikan yang lebih sempurna. Semoga penelitian ini dapat memberikan sumbangan berarti dalam dunia pendidikan. Amin.

\section{DAFTAR PUSTAKA}

Arikunto, S. (2006). Prosedur Penelitian Suatu Pendekatan Praktik. Jakarta: Rineka Cipta.

Barbour, M. (2005). Design of Web-Based Courses for Secondary Students. Journal of distance learning, 9/1.

Davis D. dan Sorrel J. (1995). Mastery Learning in Public Schools. Valdosta: Valdosta State University. http://teach.valdosta.edu/whuitt/files/mastlear.html (diakses pada 3 februari 2010)

Guskey, dkk. (1982). The Effektivenessof Mastery Learning Strategies In Undergraduete Education Courses. University of Kentucky.

Haddad, W. D. (2009). ICT for Education an Overview. http://en.wikipedia.org/ wiki/Information_and_communication_technologies (diakses pada 14 Mei 2009).

Hershkowitz, R dan Schwarz, B. (1999). The Emergent Perspective In Rich Learning Environments: Some Roles of Tools and Activities in The Construction of Sociomathematical Norms. Springer, 1/15:149-166.

Horsley, S. L. (1990). Elementary School Sciene for the 90's. Virginia: Association Supervision and curriculum Development.

Isjoni dkk. (2008). Pembelajaran Terkini. Yogyakarta: Pustaka Pelajar. 
Isjoni, Ismail, dan Mahmud. (2008). ICT Untuk Sekolah Unggul. Yogyakarta: Pustaka Pelajar.

Kaino, L M. (2008). Information and communication Technologi (ICT) developments, utilization and challenges in ICMI history. www.unige.ch/ math/ensmath/rome2008/wg4/papers/Kaino.Pdf (diakses 31 oktober 2009). 